\title{
SUATU TINJAUAN PENYEBAB KEPINDAHAN DOSEN PERGURUAN TINGGI NEGERI (PTN) KE LUAR NEGERI
}

\author{
Idi Setyo Utomo ${ }^{1}$
}

\begin{abstract}
Article discusses lecturers plan to teach abroad. This article explains the main reason of working satisfaction, those are money, working safety, schedule, and envolvement in working environment. For the last three main reasons, which are working safety, schedule, and envolvement in working environment, the lecturers generally satisfied. The main reason that is assumed to have a big influence in lecturer plan to teach abroad is bigger salary (money).
\end{abstract}

Keywords: lecturer, teaching, abroad

\section{ABSTRAK}

Artikel membahas alasan dosen untuk mengajar ke luar negeri. Artikel ini menjelaskan bahwa penyebab utama yang mempengaruhi kepuasan kerja adalah uang, keamanan pekerjaan, jadwal pekerjaan, dan keterlibatan di tempat kerja. Terhadap tiga karakteristik utama tersebut terakhir, yakni keamanan pekerjaan, jadwal pekerjaan, dan keterlibatan di tempat kerja, dosen PTN pada umumnya sudah terpuaskan. Faktor yang dianggap mempengaruhi kepergian dosen ke luar negeri adalah gaji yang lebih besar (faktor uang).

Kata kunci: dosen, mengajar, luar negeri

\footnotetext{
${ }^{1}$ Staf Pengajar Fakultas Ekonomi, UBiNus, Jakarta
} 


\section{PENDAHULUAN}

Bulan Juni 2003 dunia pendidikan nasional mengalami polemik berkaitan dengan tiga hal yang merisaukan insan di Indonesia. Masalah pertama adalah rencana pengesahan Rencana UndangUndang Sistem Pendidikan Nasional menjadi Undang-Undang yang menimbulkan pro dan kontra di masyarakat seluruh wilayah negara Indonesia. Masalah yang kedua adalah rencana kepindahan sejumlah dosen Perguruan Tinggi (PTN) ternama di Jawa dan Sumatera yang akan mengajar di beberapa negara jiran (Malysia, Singapura, dan Brunei Darussalam). Masalah yang ketiga adalah mengenai empat PTN yang sudah menjadi Badan Hukum Milik Negara (Universitas Indonesia, Institut Pertanian Bogor, Institut Teknologi Bandung, dan Universitas Gajah Mada) yang akan menerima mahasiswa baru lewat jalur khusus dengan biaya yang besar.

Pada kesempatan ini, penulis ingin memberikan komentar mengenai masalah yang kedua, yakni rencana hengkangnya rekan-rekan dosen PTN yang ingin mengajar di Malaysia, Singapura, dan Brunei Darussalam. Keinginan dosen PTN tersebut dapat dimaklumi dan sudah barang tentu tidak perlu bersikap apriori terlebih dahulu karena munculnya keinginan untuk mengajar di luar negeri pasti sudah disertai dengan pertimbangan yang matang.

\section{Permasalahan}

Dibandingkan dengan keadaan ekonomi negara Indonesia, keadaan ekonomi ketiga negara tersebut memang jauh lebih baik. Belum lagi kalau membandingkan dari aspek politik, sosial, keamanan, dan aspek hukum, tiga negara tersebut memiliki keunggulan untuk dimasuki. Bahkan, di bidang pendapatan per kapita, sejak krisis terjadi sampai saat ini, pendapatan per kapita Indonesia semakin menurun dan jauh di bawah pendapatan per kapita ketiga negara tersebut. Dalam bidang pendidikan, walaupun Indonesia memiliki sejumlah PTN ternama tetapi kemampuan PTN untuk memberikan kesejahteraan yang layak bagi tenaga pengajar atau para dosennya masih kalah jauh dibandingkan dengan kemampuan universitas dari ketiga negara tersebut dalam memberikan kesejahteraan kepada dosennya. Hal itu disebabkan sistem penggajian yang diterapkan kepada para dosen PTN adalah sistem penggajian yang diberlakukan kepada pegawai negeri sipil di Indonesia karena seluruh dosen PTN statusnya adalah juga sebagai pegawai negeri sipil.

Dengan alasan minimnya penghasilan, banyak di antara dosen PTN yang melakukan kegiatan di luar kampus, antara lain menjadi pembicara dalam seminar/workshop, menjadi tenaga konsultan atau bahkan menjadi tenaga pengajar di sejumlah Perguruan Tinggi Swasta (PTS) yang ada di satu kota dengan lokasi PTN yang bersangkutan. Oleh karena itu, wajar apabila tenaga dosen senior, apalagi lulusan luar negeri dan merasa mampu, kesempatan mengajar di luar negeri dengan imbalan yang besarnya berlipat ganda dibandingkan penghasilan sebagai dosen PTN di tanah air, tentu tidak akan dilewatkan begitu saja. 


\section{PEMBAHASAN}

Banyak pihak sangat menyayangkan maksud dosen PTN tersebut yang seolah-olah sepertinya “tidak memerhatikan mahasiswa sendiri”. Apalagi beberapa dosen PTN yang telah bergelar doktor atau magister tersebut telah memperoleh kesempatan meraih gelar kesarjanaan jenjang pascasarjana (Strata 2 dan Strata 3) di luar negeri dengan biaya negara dengan jumlah yang tidak sedikit. Sebagai gambaran mengenai mahalnya pendidikan di luar negeri, penulis mencoba mengemukakan salah satu instansi pemerintah yang cukup banyak mengirimkan pegawainya untuk menempuh jenjang pendidikan baik Strata 2 (magister) maupun Strata 3 (doktor) ke luar negeri, yaitu Badan Penelitian dan Pengembangan Pertanian. Berikut ini, penulis sajikan biaya pendidikan yang diberikan kepada para pegawai Badan Penelitian dan Pengembangan Pertanian di luar negeri yang memperoleh dana pinjaman (loan) dari Bank Pembangunan Asia (Asia Development Bank) seperti dapat dibaca pada tabel 1 di bawah ini.

Tabel 1 Biaya Pendidikan S3 (Doktor) Pegawai Badan Litbbang Pertanian ke Amerika Serikat Tahun 2002-2003

\begin{tabular}{lll}
\hline Jenis Biaya & Jumlah dalam US \$ & Keterangan \\
\hline Biaya hidup & 900 & Per bulan \\
\hline Buku & 75 & Per bulan \\
\hline Biaya penelitian & 2,650 & Per tahun \\
\hline Asuransi & 65 & Per bulan \\
\hline Biaya relokasi & 1,200 & Pada waktu berangkat dan pulang \\
\hline & & $\begin{array}{l}\text { sesuai harga tiket Jakarta - kota tujuan } \\
\text { di Amerika Serikat pp }\end{array}$ \\
Biaya tiket &
\end{tabular}

Andaikan semuanya berjalan normal dan untuk menyelesaikan pendidikan S3 diperlukan waktu selama 3 (tiga) tahun maka biaya yang harus dikeluarkan oleh pemerintah kepada seorang pegawai Badan Litbang Pertanian yang belajar di Amerika Serikat sebagai berikut.

- Biaya hidup US\$ $900 \times 36$ bulan = US \$32,400

- Buku US\$ 75 X 36 bulan = US \$2,700

- Biaya penelitian US\$2,650 X 3 tahun = US \$7,950

- Asuransi US\$ 65 X 36 bulan = US \$2,340

- Biaya relokasi =US $\$ 1,200$

Jumlah = US \$ 46,590 
Dari jumlah sebesar US \$ 46,590 tersebut pegawai yang bersangkutan masih menerima tiket pergi pulang dari Jakarta ke kota tujuan di Amerika Serikat yang harganya sesuai harga tiket yang berlaku (at cost). Jika diasumsikan kurs yang berlaku saat ini untuk US \$ 1 setara dengan Rp 8.300,-maka jumlahnya dalam mata uang rupiah adalah Rp386.697.000,00 (minus biaya tiket). Biaya pendidikan di Amerika Serikat pada umumnya lebih mahal bila dibandingkan dengan biaya pendidikan di negara Asia di luar Jepang. Sebagai perbandingan, pada Tabel 2 penulis menyajikan biaya pendidikan pegawai Badan Litbang Pertanian di sejumlah negara Asia, tidak termasuk Jepang.

Tabel 2 Biaya Pendidikan S3 (Doktor) Pegawai Badan Litbang Pertanian ke Negara Asia

(Di Luar Jepang) Tahun 2002-2003

\begin{tabular}{lll}
\hline Jenis Biaya & Jumlah dalam US \$ & Keterangan \\
\hline Biaya hidup & 650 & Per bulan \\
\hline Buku & 50 & Per bulan \\
\hline Biaya penelitian & 1,750 & Per tahun \\
\hline Asuransi & 30 & Per bulan \\
\hline Biaya relokasi & 700 & Pada waktu berangkat dan pulang \\
\hline Biaya tiket & & $\begin{array}{l}\text { sesuai harga tiket Jakarta }- \text { kota tujuan } \\
\text { negara yang bersangkutan pp }\end{array}$ \\
\hline Sumber: PAATP Badan Litbang Pertanian &
\end{tabular}

Biaya pendidikan di luar negeri khususnya di Amerika Serikat, sangat besar. Apalagi jika dikaitkan dengan kondisi negara yang jumlah penganggurnya sudah mencapai 40 juta orang. Alasan utama pemerintah mengirim para dosen PTN belajar ke luar negeri meraih jenjang strata pendidikan yang lebih tinggi adalah untuk meningkatkan kualitas dosen yang bersangkutan yang kelak setelah pulang ke tanah air diharapkan dapat menularkan ilmunya kepada para mahasiswa, dengan harapan mutu lulusannya juga akan lebih baik lagi. Oleh sebab itu, sekali lagi rencana dosen PTN yang akan mengajar ke luar negeri sungguh sangat disayangkan.

Menanggapi rencana kepindahan beberapa dosen yang akan mengajar ke luar negeri ini, salah seorang ahli pendidikan kita, Winarno Surakhmad menyarankan agar pemerintah harus secepatnya mengatasi persoalan tersebut dengan meningkatkan kesejahteraan lahir dan batin para guru termasuk dosen (Kompas, Sabtu 21 Juni 2003). Berdasarkan saran ahli pendidikan tersebut, penulis beranggapan bahwa alasan utama rencana kepindahan beberapa rekan dosen PTN ternama di Jawa dan Sumatera yang ingin mengajar ke luar negeri kemungkinan besar adalah masalah kesejahteraan atau pendapatan (take home pay-nya). 
Jeff Madura dalam bukunya Pengantar Bisnis, mengemukakan bahwa motivasi karyawan dipengaruhi oleh kepuasan pekerjaan (job satisfaction) atau tingkat karyawan puas dengan pekerjaannya (Pengantar Bisnis, Buku 2, hlm.3). Selanjutnya, Jeff Madura mengemukakan bahwa, secara umum, karakteristik utama yang mempengaruhi kepuasan pekerjaan adalah uang, keamanan pekerjaan, jadwal pekerjaan, dan keterlibatan di tempat kerja. Terhadap tiga karakteristik utama tersebut terakhir, yakni keamanan pekerjaan, jadwal pekerjaan, dan keterlibatan di tempat kerja, penulis yakin bahwa rekan-rekan dosen PTN pada umumnya sudah terpuaskan.

Sebagai pegawai negeri sipil, dosen PTN sudah pasti merasa aman karena tidak akan dipecat sepanjang tidak melakukan kesalahan yang diancam dengan hukuman pidana selama 5 (lima) tahun atau lebih. Mengenai jadwal pekerjaan, penulis berharap dosen PTN juga dapat terpuaskan karena jadwal mengajar dapat diatur secara fleksibel sehingga tenaga dan pikirannya masih dapat digunakan untuk aktivitas lain yang bermanfaat terutama untuk menambah penghasilan. Mengenai keterlibatan di tempat kerja, penulis juga optimis bahwa rekan-rekan dosen PTN dengan ilmunya, sangat diharapkan keterlibatannya oleh pihak universitas tempat yang bersangkutan mengajar. Jadi, sekarang tinggal bagaimana dengan karaktersitik utama yang mempengaruhi kepuasan pekerjaan yang namanya "uang”? Setiap orang memang membutuhkan uang tetapi jangan menjadikan uang itu segala-galanya.

Dalam sebuah organisasi atau perusahaan, salah satu daya tarik untuk mengikat karyawan supaya betah bekerja (tidak keluar masuk) adalah adanya paket kompensasi karyawan yang sangat menarik. Pada perusahaan swasta, pada umumnya, paket kompensasi tersebut dapat berupa: gaji, opsi saham, komisi, bonus, pembayaran keuntungan, tunjangan karyawan, dan tunjangan jabatan (Pengantar Bisnis Buku 2, hlm.46-49). Bagi pegawai negeri sipil termasuk dosen PTN, paket kompensasi yang disediakan oleh pemerintah adalah gaji pokok, tunjangan suami/istri (5\%), tunjangan anak (2\% maksimum 2 anak), tunjangan perbaikan penghasilan 15\%, tunjangan perbaikan penghasilan, tunjangan jabatan, tunjangan beras, dan tunjangan khusus/PPH. Paket kompensasi tersebut merupakan pendapatan kotor dan masih harus dikurangi dengan potongan seperti: iuran wajib, tunjangan khusus/PPH, dan tabungan rumah berdasarkan golongan (Daftar gaji Biro Hukum dan Humas, Sekretariat Jenderal Departemen Pertanian). Tunjangan jabatan terdiri atas tunjangan jabatan struktural dan tunjangan jabatan fungsional dan seorang pegawai negeri sipil tidak diperkenankan memegang jabatan rangkap. Tidak semua pegawai negeri sipil dapat menduduki jabatan struktural maupun jabatan fungsional karena untuk memperolehnya memerlukan persyaratan tertentu dan melalui seleksi yang ketat.

Kalau diperhatikan, paket kompensasi pegawai negeri sipil termasuk dosen PTN kelihatannya cukup banyak tetapi yang menjadi masalah utama adalah gaji pokok pegawai negeri sipil faktanya memang sangat rendah. Oleh karena itu, pendapatan bersih seorang pegawai negeri sipil termasuk dosen PTN otomatis juga sangat rendah. Bayangkan kalau seorang guru besar dengan masa kerja puluhan tahun gaji bersihnya hanya sekitar Rp2.500.000,00 per bulan. Sebagai gambaran, penulis dengan status terakhir berpangkat Pembina Utama Muda, Golongan Ruang IV/C dengan masa kerja puluhan tahun hanya memiliki gaji pokok Rp1.297.500,00 (dengan jabatan struktural eselon III/a take home pay-nya per bulan hanya 2 juta rupiah lebih sedikit). Bandingkan pula dengan Winarno yang pernah bertahun-tahun mengajar di Brunei Darussalam yang dapat menerima gaji bersih sebesar Rp 75 juta-Rp80 juta per bulan (Kompas, Selasa, 24 Juni 2003). Selanjutnya, masih menurut Winarno, bahwa sekarang gaji dosen di Malaysia lebih tinggi dari pada gaji dosen di Brunei Darussalam. Hal itulah barangkali yang menjadi magnit sangat kuat yang dapat menarik minat dosen PTN ternama di Jawa dan Sumatera untuk mengajar di sana. Oleh karena itu, penulis menduga bahwa alasan utama rencana kepindahan rekan-rekan dosen PTN ternama di Jawa dan Sumatera 
yang ingin mengajar ke luar negeri adalah masalah karaktersitik utama yang pertama tadi, yaitu uang.

\section{PENUTUP}

Berdasarkan uraian tersebut, penulis juga sependapat bahwa dalam rangka menghindari kepindahan dosen PTN ternama di Jawa dan Sumatera mengajar di Malaysia, Singapura, dan Brunei Darussalam perlu disediakan adanya paket kompensasi yang menarik bagi guru dan dosen dengan perhitungan yang rasional sesuai dengan kemampuan keuangan negara Indonesia. Namun demikian, paket kompensasi tersebut janganlah menimbulkan kecemburuan bagi pegawai negeri sipil yang bukan guru dan dosen. Sebab kalau hal tersebut terjadi maka akan berdampak sangat negatif bagi produktivitas dan pengabdian pengawai negeri sipil secara keseluruhan.

Selanjutnya, penulis juga mengusulkan agar paket kompensasi bagi guru dan dosen tersebut tidak akan menimbulkan rasa rendah diri bagi dosen PTS apalagi PTS yang tidak ternama dan jumlah mahasiswanya sedikit karena penghasilan antara dosen PTN dan dosen PTS akan berbeda. Sebab apabila hal itu terjadi, nantinya tidak akan ada lagi dosen PTN yang bersedia mengajar di PTS karena gajinya kecil sekali, padahal tenaga dan pikiran rekan-rekan dosen PTN juga sangat diharapkan dapat membantu mengajar di PTS. Menurut pendapat penulis, hal tersebut akan sangat merugikan sebab nantinya dapat menimbulkan perbedaan kelas antara dosen PTN dan dosen PTS.

\section{DAFTAR PUSTAKA}

Anonim. Kompas. 21 Juni 2003.

. Kompas. 24 Juni 2003.

Salib, Saroyini W.R. 2001. Pengantar Bisnis Buku 1 dan Buku 2. Terj.dari Introduction to Business $2^{\text {nd }}$ Edition oleh Jeff Madura. United State of America. Edisi pertama. Jakarta: Penerbit Salemba Empat. 